\title{
The Monopolar Paradigm in a Polycentric World, a Review of L. V. Savin's Monograph Ordo Pluriversalis: The End of Pax Americana and the Rise of Multipolarity
}

\author{
Original review in Russian by Dr. Eugene Vertlieb \\ Translated to English by Dennis T. Faleris
}

Leonid Savin. Ordo Pluriversalis: The End of Pax Americana and the Rise of Multipolarity. Translatedby Jafe Arnold. London: Black House Publishing, Ltd., 2020. ISBN: 978-1-912759-36-1. 470 pages. $\$ 28.00$

$\mathrm{A}$ lexander Dugin, a thinker and leader of the international Eurasian movement, is confident that the best system of all is a multipolar world order, which is replacing "unipolarity." ${ }^{1}$ Defending the multipolar model is the leitmotif of the book being analyzed-political scientist Savin's Ordo Pluriversalis: The End of Pax Americana and the Rise of Multipolarity. ${ }^{2}$ The book is dedicated to the 100th anniversary of the publication of Prince Nikolai Sergeyevich Trubetskoy's "Europe and Humanity" - the first, according to Dugin, genuinely Eurasian text by a Eurasian, and the first to "overcome the West from within." Savin currently serves as Editor-in-Chief of Geopolitica.ru, the informational, analytical e-publication portal whose ardent Orthodox pro-Eurasian position prompted the U.S. State Department to label this alternative political resource as a pillar of the "ecosystem of Russian propaganda and disinformation." The Editorial Board

1 For information on Dugin and Eurasianism, see, for example, Shlapentokh, Dmitry, "Dugin, Eurasianism, and Central Asia," Communist and Post-Communist Studies, Volume 40, Issue 2, June 2007: 143-156. https://doi.org/10.1016/j.postcomstud.2007.04.002. Note that Dugin uses the English term "unipolar" vice "monopolar." These words are synonymous. Monopolar is used throughout this review.

2 The original book (in Russian) by Leonid Savin is «Ordo Pluriversalis. Возрождение многополярного мироустройства» (Москва, издательский дом «Кислород», 2020. ISBN 978-5901635-99-5), rendered, in English as "Ordo Pluriversalis. The Rebirth of a Multipolar World Order" (Moscow, "Kislorod” Publishing House, 2020).

3 According to the U.S. Department of State Global Engagement Center's August 2020 Special Report, Pillars of Russia's Disinformation and Propaganda Ecosystem, 50, "Geopolitica.ru serves as a platform for Russian ultra-nationalists to spread disinformation and propaganda targeting Western and other audiences. Inspired by the Eurasianist ideology of the Russian philosopher and ultranationalist Alexander Dugin, Geopolitica.ru views itself as caught in a perpetual information war against the Western ideals of democracy and liberalism." Until 2017, Savin served as Editor-in-Chief of the Katehon website and magazine-also blacklisted by the State Department in the August 2020 report. Also of note, Savin is founder and Editor-in-Chief of the Journal of Eurasian Affairs. 
of the portal considered the sanctions to be punitive and "part of the consistent pressure on alternative sources of information that do not accept the neoliberal agenda and the monopolar world."

Political systems analyst Savin "brainstorms" and methodically takes stock to identify the relative positions of opposing systems, and to develop the rules and mechanisms for establishing and sustaining global security for all. He affirms the fact that the old model of "democracy—good, authoritarianism-bad" no longer works; that alternatives to outdated templates and dogmas are needed; that Western mainstream neoliberalism-mondialism ${ }^{4}$ is giving way to a multipolar world where conservative values take primacy. Changes are triggering a modernization and adaptation of previous international relations models and paradigms.

This expert assessment of multipolarity is a thesaurus of non-Western approaches to a multivariant perspective on world order. In his monograph, the author shares with the reader his reinterpretation of the fundamental components of statehood, including religion, economy, the worldview of a state's peoples, its relationship to time and space, and the themes that mark its sense of security and sovereignty, its nationalism, and its civilizations. Savin's multilevel study of the polycentric structure of the global political system is based on an abundance of illustrative facts, and contains extraordinary, existentially substantive conclusions.

The balance of power is a law of politics and a condition for non-war. The disorder caused by bipolarity is a political malaise and one that exacerbates social conflict. The collapse of the USSR ended the balance of the two poles that were propping up each other's existence. For global security, a failure such as this in a system that functioned well to suppress conflicts had repercussions that are akin to a natural cataclysmic event involving a fault in the earth's crust-if, for example, the North American and Eurasian tectonic plates had diverged and giant rifts had formed-the danger which results from of an imbalance of forces: the temptation to deliver a strike on an ontological enemy with impunity. And the pathos of Winston Churchill's 1946 Fulton ("Iron Curtain") speech confirms this axiom: "[T]he old doctrine of a balance of power is unsound. We cannot afford, if we can help it, to work on narrow margins, offering temptations to a trial of strength." Consequently, even a small advantage in strategic forces provokes expansion.

With the defeat of the USSR in the Cold War, a "period of monopolarity" was established and lasted from the end of 1991-the collapse of the USSR, to September 15, 2008-the collapse of Lehman Brothers. The United States is still a superpower, but not the world's policeman; it is a center of gravity: a mediator. Political scientists J. Nye and R. Keohane assert that to serve as a global regulator,

4 Mondialism or world government is the notion of a common political authority for all of humanity, yielding a global government and a single state. Such a government could come into existence either through violent and compulsory world domination or through peaceful and voluntary supranational union. 
all that is needed is one strong state capable of establishing the basic rules governing interstate relations, and having that state possess the will to do so. The U.S. and China are the main global regulators. The emerging parallel center of powerChina - is hegemonically laying claim to a "world China zone." In the short term, there is not going to be any "era of two poles."

China is using "soft power" to achieve its aims. It has successfully made use of globalization to carry out its modernization without Westernization. It is doggedly forming its own geopolitical and geoeconomic expansion through the Shanghai Cooperation Organization and BRICS, ${ }^{5}$ and through its Chinese Free Trade Zones, respectively. Now, with its ambitious "Belt Road Initiative," it is "killing three birds with one stone": 1) it is preventing a fall into an abyss from an impending decline in the rate of economic growth;2) it is building its infrastructure facilities using its military bases for their defense; and 3) it is entangling developing nations into the scope of its strategic plans. Ancient strategies speak of China's domination over other countries in the economic, cultural, and military spheres, and of an international order based on a monopolar system in which only China sets the rules. And the three-hundred-year geopolitical confrontation with Russia has probably not been forgotten. Following the end of the Daman conflict of 1969, the Chinese so far have remained satisfied with the "harmonious neighborhood" it shares with the Russian Federation, which is considered the "rear area" of Chinese geopolitics. But China has an element in reserve and a geostrategy of "the stick" -establishing a temporary alliance with a distant state to defeat a nearby enemy state. Beijing knows how to extract maximum dividends-even from the collapse of the US-USSR bipolarity.

In a changing world, the azimuth of geopolitical confrontation is no longer West-East, but now consists of rivaling conglomerates: the European Union (EU), the North American Free Trade Agreement (NAFTA), the Great Chinese Economic Zone, Japan, and the other Association of South East Asian Nations (ASEAN) group of countries. The world is institutionally consolidated in pairs: NA-

5 The Shanghai Cooperation Organization (SCO), or Shanghai Pact, is a Eurasian political, economic, and security alliance, the creation of which was announced on 15 June 2001 in Shanghai. Established in 2006, BRICS is the acronym coined for an association of five major emerging national economies: Brazil, Russia, India, China and South Africa. The BRICS members are known for their significant influence on regional affairs.

6 Belt and Road Initiative (BRI) is a transcontinental long-term policy and investment program which aims at infrastructure development and acceleration of the economic integration of countries along the route of the historic Silk Road. The Initiative was unveiled in 2013 by China's president Xi Jinping and until 2016, was known as OBOR - One Belt One Road. See URL https:// www.beltroad-initiative.com/belt-and-road/.

7 In March 1969, the Damansky Island border conflict brought the USSR and PRC to the brink of war in the vicinity of Zhenbao (Damansky) Island on the Ussuri (Wusuli) River, near Manchuria. 
TO-CSTO; G-7-SCO; and EU-CIS. ${ }^{8}$ It is more prudent for a too interdependent world order (the flow of pharmaceuticals from China to the U.S.) to adhere not to the vector of confrontation, but to a strategy of a new "consensus of legitimacy, sovereignty and governance." $\mathrm{But}$ in the current environment of a confrontational "tripolarity," it is difficult to achieve harmony in international relations. The multipolar model was born at the Congress of Vienna in 1815 with the consolidation of geopolitics as a strategy for ensuring security and justice in international affairs. ${ }^{10}$ Multipolarity is consistent with the current geostrategy of Russia, which maintains an approach of "balancing equidistance" (or "equal proximity").

Ordo Pluriversalis provides a methodology for evaluating multipolarity as it makes a return: It is a distillation of ideas that provides a starting point; it is an anamnesis that provides the history of what has come before; it is a diagnosis of what is now; and it is a prognosis for what is to come-a forecast for the current transitioning state of world order that is undergoing restructuring. Savin examines the concept of "strategic culture"11 as a special element for identifying statehood. In the conditions of a multipolar rivalry, in which everyone is against everyone else, an imprecise understanding of the enemy is dangerous for the General Staffs of the world. This vulnerability cost Joachim von Ribbentrop the gallows, and Adolf Hitler, defeat in the war.

Those involved in developing new systems of international relations and global politics will find it useful to become acquainted with the concepts that Savin offers-the theory of neopluralism, the synthesis of aesthetic politics, and the Fourth Political Theory. ${ }^{12}$

Particularly attractive to those who are non-liberalism-oriented is the author's theory of sustainable politics, which is based on holistic conservative think-

8 NATO: North Atlantic Treaty Organization; CSTO: The Collective Security Treaty Organization; G-7: Group of Seven; SCO: Shanghai Cooperation Organization; EU: European Union; CIS: Commonwealth of Independent States.

9 Savin 2020, 31.

10 Savin 2020, 79.

11 The concept of strategic culture has become widely used in the field of international relations, primarily in the context of efforts to explain the distinctive strategic behaviors of states through reference to their unique strategic properties. See https://oxfordre.com/politics/politics/ view/10.1093/acrefore/9780190228637.001.0001/acrefore-9780190228637-e-320, among other sources. Interestingly, a course was developed and taught by the author of this review, Dr. Vertlieb, entitled "The Russian Mind." In it, considerable emphasis was given to the strategic importance of culture in geopolitics. The course was taught at the George C. Marshall European Center for Security Studies, an American-German security and defense studies institute that offers graduate-level resident programs to military and civilian government officials from around the world.

12 Savin 2020; see 403, 407, and 423, for major sections addressing "Neopluralism," "Synthesis Theory," and "Dasein and the Fourth Political Theory," respectively. 
ing. ${ }^{13}$ The basis for bringing together those who support sustaining balance in the global community may be the rejection of radical liberalism, which is characteristic for Europeans, whether social democrats or right-wing Republicans-the Gaullist-Adenauer types. Russia, in the face of anarchic riots of the century before last, substituted the paradigm of a spiritual-civil-oriented society for moderate liberalism. "Only the energy of a sensible and liberal conservatism," wrote the Russian scientist and political thinker of the century before last, B. N. Chicherin, "can save society from endless wobbling."

Savin's book is striking in the abundance of scientific methodologies that he proposes for describing a new type of world order: a system of systems, neofunctionalism, complex adaptive systems, relationism, multiplexity, polylogue, systase, and syneresis. ${ }^{14}$

With the author's focusing of the issues, the blind spots caused by the tunnel-vision mindset of today's postmodern man disappear, and he gains sight. This is what expands the boundaries of knowledge of both man and the world. Becoming acquainted with the Eurasian-conservative point of view on polycentricity will aid the political systems analyst in developing optimal foreign policy strategies and a multipolar-polycentric-pluriversal approach to political science-an indispensable innovation for a global security system given the current period of turbulent global geopolitical disturbances. The potential for conflict to arise in a multipolar world depends on how successful the strategic integration of the components is under the single umbrella of a power functioning in the role of a referee to settle disagreements. This approach is close to the ideas of Karl Schmitt, Richard Rosecrantz, and Alexander Dugin. ${ }^{15}$

\section{Prof. Eugene A. Vertlieb}

President of the International Institute for Strategic Assessments and Conflict Management (IISACM-France); Executive Director of the Western Policy Forecasting Department for Slavic Europe, (Munich, Germany); Participating Member of the Lisbon-Vladivostok Initiative (France).

\footnotetext{
13 Savin 2020, 419.

14 Savin, 431. Chapter 13, entitled "Multipolar Praxis," addresses these and other scientific methodologies for describing a new type of world order.
}

15 Savin 2020, 53. 
Dr. Eugene A. Vertlieb is a Russian-born dissident bearing US citizenship and currently living in France. He received a B.A. at Leningrad (Sankt-Peterburg) State University, a $\mathrm{PhD}$ at the University of North Carolina, and completed a postdoctoral internship at the Russian Academy of Public Administration in the Russian Federation. Dr. Vertlieb has held a variety of positions including Professor at the Marshall European Center for Security Studies, Germany, and at the Institute of International Relations (US). He is an author of several books and articles on geopolitics. Dr. Vertlieb has also served as Political adviser to the Committee on International Affairs and International Relations, Kyrgyzstan. He is currently President of the International Institute for Strategic Assessments and Conflict Management (IISACM-France); Executive Director of the Western Policy Forecasting Department for Slavic Europe, (Munich, Germany); and Participating Member of the Lisbon-Vladivostok Initiative (France).

Dennis T. Faleris received a B.S. from the University of Michigan and a Master's Degree in Russian Linguistics from Georgetown University. Mr. Faleris worked as an instructor, translator, senior intelligence analyst, and manager at the National Security Agency for more than thirty-five years. He currently resides in Annapolis, Maryland. 


\title{
Парадигма монополярья в полицентричном мире, Рецензия на монографию Л. В. Савина «Ordo Pluriversalis: Возрождение многополярного мироустройства»
}

\author{
Автор оригинального обзора на русском Д-р Евгений А. Вертлиб \\ Перевёл с русского на английский Деннис Т. Фалерис
}

Савин, Л. Ordo Pluriversalis. Возрождение многополярного мироустройства. Издательский дом «Кислород», 2020.

ISBN 978-5-901-635-99-5. 592 с., с ил.

Мыслитель и лидер Евразийского движения Александр Дугин уверен, что лучшая из систем - многополярное мироустройство, идущее на смену «унополярью» ${ }^{1}$. Отстаивание многополюсной модели миропорядка - лейтмотив анализируемой монографии политолога Л. В. Савина ${ }^{2}$. Книга посвящена 100 -летию выхода в свет работы князя Н. С. Трубецкого «Европа и человечество» - первого, по мнению Дугина, собственно евразийского текста евразийца номер один «в преодолении Запада изнутри». Информационно-аналитическое издание «Геополитика», возглавляемое Леонидом Савиным, своей ярой ортодоксально проевразийской позицией побудило Государственный департамент США счесть этот альтернативный политический ресурс одним из столпов «экосистемы российской пропаганды и дезинформации». Редакция же этого портала считает санкции карательными - «частью последовательного давления на альтернативные источники информации, не принимающие неолиберальную повестку дня и однополярный мир».

Системный аналитик Леонид Савин проводит «мозговой штурмаудит» для выявления диспозиции противоборствующих систем

1 Униполярный и однополярный - синонимы. По-английски, “unipolar" или “monopolar." В английском переводе, будем употреблять “monopolar." Александр Дугин «итальянообразно» использует термин «унополярное мироустройство».

2 Ordo Pluriversalis: Возрождение многополярного мироустройства. Издательский дом «Кислород», Москва, 2020. Издание на английском переводе опубликовано под названием Ordo Pluriversalis: The End of Pax Americana and the Rise of Multipolarity." Black House Publishing Ltd, London , 2020. 
и выработки правил и механизмов становления и функционирования глобальной безопасности для всех. Констатируется факт, что старая модель «хорошая демократия против плохого авторитаризма» уже не работает; что потребны альтернативы устаревшим шаблонам и догмам; что западный мейнстрим неолиберализма-мондиализма уступает позиции многополярному миру с приматом консервативных ценностей. Изменения становятся триггером модернизации и адаптации прежних моделей и схем международных отношений.

Данная экспертная оценка многополярности - тезаурус неЗападного подхода к многовариантной перспективе мироустройства. В монографии переосмысливаются фундаменталы государственности, включающие в себя религию, экономику, мировоззренческие особенности народов, отношение ко времени и пространству, темы безопасности и суверенитета, национализма и цивилизаций. Это многоуровневое исследование полицентричной структуры глобальной политической системы базируется на обилии иллюстрирующих фактов и содержит оригинальные экзистенциально-сущностные выводы.

Баланс сил - закон политики и условие невойны. Биполярное расстройство - это недомогание политики и обострение противоречий в социуме. С распадом СССР закончилось равновесие взаимосдерживающих полюсов. Для глобальной безопасности такой сбой в отлаженной системе гашения конфликтов по резонансу соотносим с природным катаклизмом разлома земной коры, когда Северо-Американская и Евразийская тектонические плиты разошлись и возникли гигантские рифты - опасность последствий разбалансировки паритета сил: соблазн безнаказанного удара по онтологическому врагу. И пафос Фултонской речи 1946 года Уинстона Черчилля подтверждает эту аксиому: «старая доктрина равновесия сил теперь непригодна. Мы не можем позволить себе - насколько это в наших силах - действовать с позиций малого перевеса, который вводит во искушение заняться пробой сил». Следовательно: даже малый перевес стратегических сил провоцирует экспансию.

«Однополярный момент»американоцентнричного иропорядка длился с конца 1991 (распад СССР) по 15 сентября 2008 года (крах Lehman Brothers). США всё ещё сверхдержава. Но не глобальный страж, а центр гравитации: медиатор. Учёные Дж. Най и Р. Кеохейн считают, что в качестве глобального регулятора достаточно одного сильного государства, способного утверждать основные правила, регулирующие межгосударственные отношения, и обладающего волей 
поступать таким образом. Формирующийся параллельный центр силы гегемонистски претендует на свой мировой China-пояс. Однако в краткосрочной перспективе не наступит «эпоха двух полюсов».

Китай «мягкой силой» добивается желаемого. Он удачно использовал глобализацию для проведения модернизации без вестернизации. Упорно формирует собственное геополитическое (ШОС, БРИКС) и геоэкономическое (зоны свободной торговли) пространства. Своим амбициозным проектом «Один пояс - один путь» убивает сразу трёх зайцев: 1) предотвращает падение в «бездну от надвигающегося снижения темпов экономического роста»; 2) строит и защищает военными базами свои инфраструктурные объекты; 3) ввязывает развивающиеся страны в орбиту китайских стратегических планов. В их старинных стратегмах говорится о доминировании над другими странами в экономической, культурной и военной сферах и о «международном порядке, основанном на однополярной системе», правила в которой устанавливает только Китай. Наверняка не забыто ими трёхсотлетнее геополитическое противостояние с Россией. После Даманского конфликта 1969 года пока китайцев устраивает «гармоничное соседство» с РФ, рассматриваемой «тылом» китайской геополитики. Ноесть унихпрозапаси геостратегия кнута:установления временного союза с отдалённым государством для разгрома ближнего врага. Пекин умеет извлекать максимальные дивиденды - даже из крушения биполярности США-СССР.

В меняющемся мире азимут геополитического противостояния уже не Запад-Восток, а соперничающие конгломераты: Европейский Союз, Североамериканская зона свободной торговли (НАФТА), зона «большой китайской экономики», Япония и группа стран АСЕАН. Мир институционально попарно консолидирован (НАТО-ОДКБ, Г7ШОС, ЕС-СНГ) $)^{3}$. Слишком взаимозависимому мироустройству (в США фармацевтика из Китая) благоразумнее придерживаться вектора «консенсуса легитимности, суверенности и управления». Но в нынешнем конфронтационном «трёхполюсье» трудно достичь гармонии в международных отношениях. Модель многополярья родилась с упрочением Венском конгрессом 1815 года геополитики как стратегии обеспечения безопасности и справедливости в международных делах. Многополярность соответствует нынешней геостратегии России, придерживающейся линии «балансирующей

3 НАТО: Организация Североатлантического договора; ОДКБ: Организация Договора о Коллективной Безопасности; Г-7: Группа Семи; ШОС: Шанхайская организация сотрудничества; ЕС: Европейский Союз; СНГ: Содружество Независимых Государств. 
равноудалённости» (или «равноприближённости»).

Книга Л. Савина - методология оценки возвращающейся многополярности: концентрат проподевтики (начала начал), анамнеза (что предшествовало), диагностики (что есть) и прогноза (что будет) нынешнего переходного состояния переформатирования миропорядка. Как особый идентификационный элемент, важный для государственности, рассматривается концепция стратегической культуры ${ }^{4}$. В условиях многополярного противоборства «всех против всех» неточное знание противника опасно для Генштабов. Эта уязвимость стоила Иоахиму фон Риббентропу виселицы, а Адольфу Гитлеру поражения в войне.

Для разработчиков систем новых международных отношений и глобальной политики полезно ознакомиться с выдвинутыми Л. Савиным концепциями: теорией неоплюрализма, синтезом эстетической политики и четвертой политической теорией. Особо притягательна для внелиберально ориентированных авторская теория устойчивой политики, которая опирается на целостное консервативное мышление. Основой сближения сторонников устойчивого равновесия в мировом сообществе может стать отвержение радикального либерализма, что характерно для европейских как социал-демократов, так и для правых республиканцев - голлистко-аденауэровского типа. Россия в ситуации анархических беспорядков в позапрошлом веке сменила парадигму духовно-гражданской ориентации общества - на умеренный либерализм. «Только энергия разумного и либерального консерватизма, - писал российский учёный и политик Б. Н. Чичерин, - может спасти общество от бесконечного шатания».

Поражает в книге Л. Савина обилие предлагаемых научных методик описания нового типа мироустройства: система систем, неофункционализм, комплексные адаптивные системы, реляционизм, мультиплексность, полилог, систаза и синерезис.

Слепые зоны туннельного мышления человека эпохи постмодерна в авторской фокусировке обретают “зрячесть”. Что раздвигает границы познания как человека, так и мира. Это знакомство с евразийско-консервативной точкой зрения на полицентричность поможет системной аналитике в выработке оптимальных внешнеполитических стратегий и многополярно-полицентрично-

4 Интересно, что автор читал дипломатам и военным в George C. Marshall European Center, Germany, свой спецкурс “The Russian Mind.” В ходе курса, большое внимание было уделено «стратегическому значению культуры». 
плюриверсальномуподходув политическихнауках, столь необходимых новаций для системы глобальной безопасности в период турбулентных геополитических пертурбаций. Потенциал конфликтогенности в многополярье зависит от результата стратегической интеграции его составных компонентов, под единым зонтиком сильной державы в функции всемирного рефери в спорах. Такой подход близок к идеям Карла Шмитта, Ричарда Роузкранца, и Александра Дугина.

Проф. Евгений Александрович Вертлиб

Президент Международного института стратегических оценок и управления конфликтами (МИСОУК-Франиия); Ответственный редактор отдела прогнозирования политики Запада «Славянской Европы» (Мюнхен, Германия); Участвующий Член Инициативы «Лиссабон-Владивосток» (Франция) 